\title{
Pengembangan Modul Pembelajaran Kimia Berbasis Aplikasi Android pada Materi Larutan Elektrolit dan Nonelektrolit
}

\author{
Rizky Jasahuldia ${ }^{1 *}$, Jeckson Siahaan ${ }^{2}$, Dwi Laksmiwati ${ }^{3}$, I Nyoman Loka ${ }^{4}$ \\ $123{ }^{4}$ Program Studi Pendidikan Kimia FKIP Universitas Mataram. Jalan Majapahit No. 62 \\ Mataram, NTB 83112, Indonesia. \\ *Coressponding Author, Email: Rizkyjasa945@gmail.com
}

Received: 13 Juli 2021

Accepted: 30 November 2021 Published: 30 November 2021

doi: 10.29303/cep.v4i3.2800

\begin{abstract}
Abstrak
Penelitian ini merupakan penelitian pengembangan (Research and Development) yang bertujuan untuk mengetahui kelayakan dan kepraktisan modul pembelajaran kimia berbasis aplikasi android pada materi larutan elektrolit dan nonelektrolit. Desain penelitian yang digunakan adalah model pengembangan Borg dan Gall. Penelitian ini terbatas hanya sampai 5 tahap yaitu riset dan pengumpulan informasi, perencanaan, pengembangan produk awal, uji lapangan produk awal dan revisi produk awal. Sampel dalam penelitian ini adalah 40 siswa kelas X MIPA SMAN 1 Keruak yang diambil secara random proporsional yang terdiri dari 10 siswa kelas X MIPA 1, 10 siswa kelas X MIPA 2, 10 siswa kelas X MIPA 3 dan 10 siswa kelas X MIPA 4. Hasil penilaian kelayakan oleh ketiga validator menggunakan indeks Aiken diperoleh nilai $\mathrm{V}=0,88$ yang menunjukkan bahwa modul pembelajaran kimia berbasis aplikasi android pada materi larutan elektrolit dan nonelektrolit sangat layak untuk diujicobakan. Hasil uji kepraktisan yang diperoleh dari angket respon siswa menunjukkan rata-rata kepraktisan untuk semua aspek sebesar $82 \%$ yang berarti bahwa modul yang dikembangkan sangat praktis untuk digunakan.Secara umum, berdasarkan data tersebut dapat disimpulkan bahwa modul pembelajaran kimia berbasis aplikasi android pada materi larutan elektrolit dan nonelektrolit yang dikembangkan bersifat sangat layak dan praktis.
\end{abstract}

Kata Kunci: Modul Pembelajaran, Aplikasi Android, Larutan Elektrolit dan Nonelektrolit.

\section{Development of Chemical Learning Module Based Android App on Electrolyte \& Nonelectrolyte Solution Material}

\begin{abstract}
This development research aims to determine the feasibility and practicality of a chemical learning module based on android app on electrolyte \& nonelectrolyte solutions. The research design used refers to Borg and Gall development model which is restricted into 5 stages namely research and information gathering, planning, initial product development, initial product field test, and initial product revision. The sample in this research is 40 students of grade X MIPA SMAN 1 Keruak taken at random proportionally that consists of 10 students of grade X MIPA 1, 10 students of grade X MIPA 2, 10 students of grade X MIPA 3 and 10 students of grade X MIPA 4. The results of the feasibility assessment by the three validators using the Aiken index obtained a value of $V=0.88$ indicates that the chemistry learning module based on the android application on electrolyte and nonelectrolyte solutions is very feasible to be tested. The results of the practicality test obtained from student response questionnaires showed an average practicality for all aspects of $82 \%$, which means that the developed module is very practice to be used. In general, based on the data, it can be concluded that the android application-based chemistry learning module on electrolyte and nonelectrolyte solutions developed is very feasible and practical.
\end{abstract}

Keywords: Learning Module, Android Application, electrolyte and nonelectrolyte solutions 


\section{Chemistry Education Practice, 4 (3), 2021 - 277}

Jasahuldia, Siahaan, Laksmiwati, Loka

\section{PENDAHULUAN}

Kimia merupakan salah satu mata pelajaran yang sangat penting untuk dipelajari karena seluruh materi di alam semesta merupakan zat-zat kimia yang berproses melalui reaksi kimia. Pada dasarnya, ilmu kimia mempelajari tentang materi yang meliputi struktur, susunan, sifat, dan perubahan materi serta energi yang menyertainya (Sappaile, 2019). Suatu materi yang dipelajari bersifat abstrak dan cukup sulit dimengerti, sehingga pelajaran kimia seringkali dianggap tidak menarik untuk dipelajari dan kurang diminati siswa (Ariani, 2020).

Berdasarkan fakta dari beberapa hasil penelitian bahwa kurangnya minat dan perhatian siswa pada saat proses pembelajaran kimia berlangsung menyebabkan siswa mengalami kesulitan belajar kimia (Rusda \& Utiya, 2012). Suasana kelas ketika pembelajaran kimia berlangsung cenderung pasif dan membosankan karena kurangnya minat dan perhatian siswa ketika belajar. Siswa mengalami kesulitan dalam memahami konsep-konsep yang ada dalam kimia seperti ketidakmampuan dalam menghubungkan aspek makroskopis dan mikroskopis (Ristiyani, \& Bahriah, 2016; Supriadi, 2021). Menurut Chittleborough (2010) manyatakan ilmu kimia memiliki tiga kompenen dasar yaitu aspek makroskopis (dapat dilihat), submikroskopis (tatanan molekuler) dan simbolik.

Salah satu materi pokok yang membuat siswa kesulitan dalam memahami konsep kimia adalah materi larutan elektrolit dan nonelektrolit yang merupakan salah satu materi kelas $\mathrm{X}$ dengan kompetensi dasar menganalisis sifat larutan elektrolit dan nonelektrolit berdasarkan daya hantar listriknya. Materi larutan elektrolit dan nonelektrolit merupakan salah satu materi yang memiliki konsep kimia submikroskopis (Syaifuddin, 2014). Suyanti (2012) menyatakan konsep kimia sulit diobservasi langsung karena terkait molekul yang submikroskopis.

Keberhasilan proses belajar dipengaruhi oleh banyak faktor, baik faktor internal maupun faktor eksternal (Riyani, 2015). Faktor internal adalah faktor yang berasal dari dalam diri siswa diantaranya motivasi, minat, dan kemampuan berpikir siswa. Faktor eksternal adalah faktor yang berasal dari luar, diantaranya lingkungan belajar, keluarga,.masyarakat dan sekolah (Priyayi, 2016). Proses belajar mengajar secara tatap muka sekarang ini sudah tidak bisa dilakukan secara normal karena adanya pandemi COVID-19. Oleh karena itu, guru harus mampu menyiapkan segala kebutuhan belajar termasuk bahan ajar sebagai salah satu media yang digunakan untuk menyampaikan materi demi tercapainya tujuan pembelajaran yang diinginkan. Bahan ajar adalah seperangkat materi pelajaran yang mengacu pada kurikulum yang digunakan dalam rangka mencapai standar kompetensi dan kompetensi dasar yang telah ditentukan (Lestari, 2013; Bahtiar, 2015).

Berdasarkan hasil wawancara dengan salah satu guru kimia SMAN 1 Keruak mengatakan bahwa dalam proses pembelajaran sulit bagi guru membuat siswa mengajukan pertanyaan yang berkualitas. Selama pembelajaran secara daring guru biasanya menyiapkan bahan ajar yang bersumber dari youtube, modul atau e-book yang diperoleh dari internet. Bahan ajar yang berupa modul atau $e$ book biasanya hanya berisi tulisan dan gambar statis sehingga kurang menarik yang dapat menyebabkan siswa cepat bosan dan malas membacanya, serta dapat menyebabkan siswa kurang memahami materi jika tanpa ada bimbingan oleh guru. Oleh karena itu, untuk mengatasi masalah tersebut guru membutuhkan variasi bahan ajar yang lebih kreatif, inovatif, dan praktis agar proses belajar mengajar dapat maksimal seperti ketika belajar secara tatap muka.

Salah satu contoh bahan ajar yang dapat dikembangkan adalah modul. Modul merupakan suatu cara pengorganisasian materi pelajaran yang memperhatikan fungsi pendidikan (Santyasa, 2009). Dalam kurikulum 2013 menyarankan proses pembelajaran berdasarkan pendekatan saintifik dengan harapan pembelajaran sains yang dilakukan dapat membantu siswa untuk terampil dalam menggunakan media, teknologi, informasi dan komunikasi (TIK) yang dibutuhkan pada abad 21 (Kemendikbud, 2017). Dengan demikian, peneliti tertarik untuk mengembangkan modul berbasis aplikasi android yang dikemas dengan menarik untuk membantu siswa dalam memahami materi kimia khususnya materi larutan elektrolit dan nonelektrolit.

Android adalah sistem operasi untuk perangkatmobile berbasis linux yang mencakup sistem operasi, middleware dan aplikasi (Safaat, 2012). Modul berbasis aplikasi android ini tidak hanya berisi materi pembelajaran dan gambar, tetapi juga berisi media lain berupa suara, animasi, dan bahkan video praktikum sederhana yang tidak membutuhkan akses internet.

Modul berbasis aplikasi android dapat diinstal pada android masing-masing siswa, sehingga siswa dapat mengaksesnya dimana saja 


\section{Chemistry Education Practice, 4 (3), 2021 - 278}

Jasahuldia, Siahaan, Laksmiwati, Loka

dan kapan saja.Oleh karena itu, peneliti mengambil judul "Pengembangan Modul Pembelajaran Kimia Berbasis Aplikasi Android pada Materi Larutan Elektrolit dan Nonelektrolit" untuk menghasilkan modul berbasis aplikasi android yang layak dan praktis.

\section{METODOLOGI PENELITIAN}

Penelitian ini dilaksanakan di sekolah SMAN 1Keruak pada semester II (Genap) Tahun Ajaran 2020/2021. Penelitian ini termasuk penelitian dan pengembangan (Research and Development) yang mengadaptasi model pengembangan Borg and Gall. Dalam model pengembangan Borg and Gall terdapat 10 tahapan pengembangan yaitu: 1) riset dan pengumpulan informasi; 2) perencanaan; 3) pengembangan produk awal; 4) uji lapangan produk awal; 5) revisi produk awal; 6) uji lapangan produk dalam skala yang lebih luas; 7) revisi produk; 8) uji lapangan pada skala yang lebih luas; 9) revisi akhir produk berdasarkan hasil analisis data pada uji lapangan akhir, dan 10) desiminasi dan melaporkan produk akhir hasil penelitian dan pengembangan (Sanjaya, 2013). Namun, penelitian ini terbatas sampai 5 tahap diantaranya tahap riset dan pengumpulan informasi, perencanaan, pengembangan produk awal, uji lapangan produk awal, dan revisi produk awal. Adapun yang dikembangkan dalam penelitian ini adalah modul pembelajaran kimia berbasis aplikasi android pada materi larutan elektrolit dan nonelektrolit.

Penelitian ini bertujuan untuk menentukan bagaimana kelayakan dan kepraktisan modul pembelajaran yang dikembangkan. Populasi dalam penelitian ini adalah seluruh siswa kelas X MIPA SMAN 1 Keruak tahun ajaran 2020/2021 yang berjumlah 124 siswa. Teknik pengambilan sampel siswa adalah dengan menggunakan teknik random proporsional (Proportional Random Sampling). Teknik ini merupakan pengambilan anggotasampel dari populasi dilakukan dengan proporsi sama.

Pengambilan sampel untuk penelitian besarnya yang dapat dipakai apabila subjeknya kurang dari 100, lebih baik diambil semua sehingga penelitiannya merupakan penelitian populasi. Tetapi jikajumlah subjeknya besar (lebih dari 100 orang)dapat diambil antara $10-15 \%$ atau $20-25 \%$ ataulebih (Arikunto, 2010).Dalam penelitian ini total sampel yang digunakan peneliti adalah 40 siswa yang diambil di setiap kelas dengan proporsi yang sama diambil sebanyak $32 \%$ dari jumlah total populasi, sehingga diperoleh 10 siswa untuk kelas $X$ MIPA I, 10 siswa kelas X MIPA II, 10 siswa kelas X MIPA III, dan 10 siswa kelas X MIPA IV.
Penelitian ini menggunakan instrumen lembar kelayakan modul pembelajaran dan angket respon siswa. Lembar kelayakan digunakan untuk mengetahui tingkat kelayakan modul pembelajaran yang dianalisis menggunakan statistik Aiken's V yang dinilai oleh tiga orang validator. Angket respon siswa dianalisis menggunakan rumus perhitungan persentase untuk menentukan kepraktisan modul pembelajaran yang dikembangkan.

\section{HASIL DAN PEMBAHASAN}

Data hasil kelayakan diperoleh dari lembar kelayakan modul yang sudah dinilai oleh validator. Analisis data yang digunakan dalam menentukan tingkat kelayakan modul pembelajaran adalah indeks Aiken. Berdasarkan hasil analisis data, diperoleh ketiga validator memberikan penilaian sangat layak terhadap modul pembelajaran yang dikembangkan karena memiliki nilai kelayakan sesuai indeks Aiken yang berada pada kisaran $0,8<\mathrm{V} \leq 1$ yaitu $\mathrm{V}$ sebesar 0,88 .

Modul pembelajaran yang telah diuji kelayakannya selanjutnya dilakukan analisis untuk mengetahui tingkat reliabilitas dengan menggunakan rumus percentage of agreement $(R)$. Berdasarkan kelima komponen penilaian diperoleh nilai rata-rata $\mathrm{R}$ sebesar 0,93 atau $P A=93 \%$. Nilai rata-rata $R$ setiap komponen yaitu komponen kegrafikan yang memperoleh nilai rata-rata $\mathrm{R}=0,94$ atau $\mathrm{PA}=94 \%$, komponen penyajian dengan nilai rata-rata $\mathrm{R}=1$ atau $\mathrm{PA}=100 \%$, komponen kelayakan isi dengan nilai rata-rata $\mathrm{R}=0,90$ atau $\mathrm{PA}=90 \%$, komponen kepraktisan dengan nilai rata-rata $\mathrm{R}=0,96$ atau $\mathrm{PA}=96 \%$, dan komponen kebahasaan dengan nilai rata-rata $\mathrm{R}=0,86$ atau $\mathrm{PA}=86 \%$.

Berdasarkan hasil analisis tersebut, disimpulkan bahwa modul berbasis aplikasi android yang dikembangkan layak dan reliabel. Hal ini sesuai dengan penelitian yang dilakukan oleh Ibrahim et. al. (2020) yang menunjukkan bahwa validitas untuk semua perangkat pembelajaran yang divalidasi oleh ahli memiliki validitas tinggi dan reliabel. Dengan demikian, modul pembelajaran sudah siap diujicobakan pada siswa atau sampel penelitian untuk mengetahui apakah modul yang dikembangkan praktis. 


\title{
Chemistry Education Practice, 4 (3), 2021 - 279
}

\author{
Jasahuldia, Siahaan, Laksmiwati, Loka
}

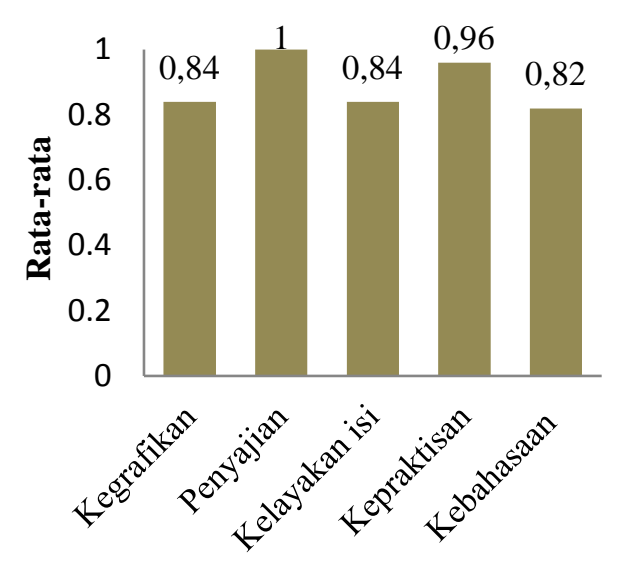

Gambar 1. Kelayakan Modul Pembelajaran

Berdasarkan gambar 1, hasil uji kelayakan modul pembelajaran kimia berbasis aplikasi android pada materi larutan elektrolit dan nonelektrolit yang dikembangkan berada pada kategori sangat layak dengan nilai rata-rata $\mathrm{V}$ yang diperoleh sebesar 0,88 . Nilai rata-rata yang diperoleh paling rendah sebesar $\mathrm{V}=0,82$ yang terdapat pada aspek kebahasaan dan nilai rata-rata yang paling tinggi sebesar $\mathrm{V}=1$ yang terdapat pada aspek penyajian. Hal tersebut menunjukkan bahwa modul berbasis aplikasi android ini sangat .Berdasarkan hasil tersebut dapat disimpulkan bahwa modul pembelajaran kimia berbasis aplikasi android pada materi larutan elektrolit dan nonelektrolit tergolong sangat layak dan dapat digunakan untuk uji selanjutnya yaitu uji kepraktisan.

Selanjutnya, uji kepraktisan yang dilakukan dengan menyebar angket kepada semua sampel atau siswa yaitu sebanyak 40 siswa. Angket respon siswa yang digunakan untuk menentukan kepraktisan modul pembelajaran terdiri atas 20 butir pertanyaan yaitu: 8 butir pertanyaan untuk komponen kemenarikan modul pembelajaran, 8 butir untuk komponen kemudahan penggunaan modul pembelajaran, dan 4 butir untuk komponen manfaat modul pembelajaran.

Berdasarkan hasil analisis angket respon siswa yang telah dilakukan diperoleh persentase kepraktisan modul pembelajaran sebesar $82 \%$ yang berarti bahwa modul pembelajaran kimia berbasis aplikasi android yang dikembangkan sangat praktis karena memiliki persentase kepraktisan yang berada pada kisaran $81 \%<x \leq 100 \%$. Rata-rata $82 \%$ ini diperoleh berdasarkan hasil analisis angket respon siswa yang terdiri dari tiga aspek penilaian yaitu kemenarikan modul yang memperoleh nilai kepraktisan $81 \%$, aspek kemudahan penggunaan modul dengan nilai kepraktisan $83 \%$ dan aspek manfaat modul dengan nilai kepraktisan $83 \%$.
Hasil uji kepraktisan yang diperoleh menunjukkan bahwa siswa memberikan respon sangat baik terhadap modul pembelajaran yang dikembangkan.Hal ini sesuai dengan Murtafi'ah (2014) bahwa respon peserta didik terhadap semua aspek berada diatas $80 \%$ berarti setiap aspek direspon positif oleh peserta didik.Selain itu, persentase tiap butir pernyataan berada pada $\geq 70 \%$. Hal tersebut menurut Sanusi, Suprapto, dan Apriandi (2014) jika persentase respon peserta didik pada tiap butir pernyataan angket respon menunjukkan diatas $70 \%$ memiliki kualifikasi "Tinggi" dan "Sangat Tinggi". Dengan demikian respon peserta didik terhadap modul pembelajaran berbasis aplikasi android sangat tinggi.

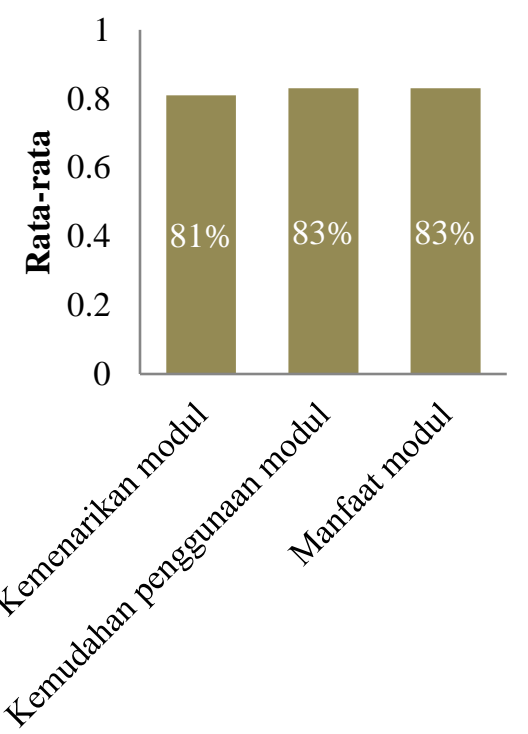

Gambar 2. Kepraktisan Modul Pembelajaran

Berdasarkan gambar 2, analisis angket respon siswa menggunakan indeks kepraktisan diketahui bahwa nilai rata-rata pada ketiga aspek yang dinilai tidak mencapai nilai maksimal yaitu $100 \%$ karena hasil penilaian tiap butir pernyataan angket tidak semua mendapat nilai maksimal yaitu 4 atau kategori sangat setuju terhadap pernyataan dalam angket, selain itu masih terdapat komentar/saran perbaikan yang diberikan siswa untuk menyempurnakan modul yang dikembangkan. Akan tetapi, perolehan nilai rata-rata uji kepraktisan tetap termasuk dalam kategori sangat praktis dengan nilai sebesar $82 \%$ karena memiliki persentase kepraktisan yang berada pada kisaran $81 \%<x \leq 100 \%$. Dengan demikian, tingkat kepraktisan modul pembelajaran yang dikembangkan peneliti sangat praktis untuk digunakan. 


\section{Chemistry Education Practice, 4 (3), 2021 - 280}

Jasahuldia, Siahaan, Laksmiwati, Loka

\section{SIMPULAN}

Berdasarkan hasil penelitian dapat disimpulkan bahwa modul pembelajaran kimia berbasis aplikasi android pada materi larutan elektrolit dan nonelektrolit yang telah dikembangkan sangat layak dan rata-rata siswa SMAN 1 Keruak merespon dengan sangat baik sehingga, modul yang dikembangkan tersebut sangat praktis untuk digunakan dalam proses pembelajaran.

\section{DAFTAR PUSTAKA}

Ariani, S., Effendy, E., \& Suharti, S. (2020). Model Mental Mahasiswa Pada Fenomena Penghilangan Karat Melalui Elektrolisis. Chemistry Education Practice, 3(2), 55-62.

Arikunto, Suharsimi. (2010). Prosedur Penelitian Suatu Pendekatan Praktik (Edisi Revisi). Jakarta: Rineka Cipta.

Bahtiar, E. T. (2015, October). Penulisan bahan ajar. In Artikel disajikan dalam kegiatan Conference Paper di Bogor.

Chittleborough, G.D. (2010). Studentgenerated submicro diagrams: a useful tool for teachingand learning chemicalequation and stoichiometry.CE: Research and Practice,11, 154-164.

Ibrahim, I., Kosim.,\& Gunawan, G. (2020). Validitas Perangkat Pembelajaran Fisika berbasis Model Discovery Dengan Pendekatan Konflik Kognitif. Jurnal Pendidikan Fisika dan Teknologi.15(3): 214-218.

Kemendikbud. (2017). Model Silabus Mata Pelajaran SMA/MA. Jakarta: Kemendikbud.

Lestari, Ika. (2013). Pengembangan bahan Ajar Berbasis Kompetensi: Sesuai dengan Kurikulum Tingkat satuan Pendidikan. Padang : Akademi Permata.

Priyayi, Desy Fajar. (2016). Analisis Bahan Ajar Model Pembelajaran Alid (Accelerated Learning Included By Discovery) pada Materi Jaringan Tumbuhan Kelas XI SMAN 7 Surakarta. Jurnal Pendidikan Sains. 04 (01): 29.

Ristiyani, E., dan Bahriah, E. S. (2016). Analisis kesulitan Belajar Kimia Siswa Di SMAN X Kota Tangerang Selatan.Jurnal Penelitian dan Pembelajaran IPA.UIN Syarif Hidayatullah. 2 (1): 18-29.

Riyani, Y. (2015). Faktor-faktor yang mempengaruhi prestasi belajar mahasiswa (studi pada mahasiswa Jurusan Akuntansi Politeknik Negeri Pontianak).

Rusda, Q., dan Utiya, A. (2012). Implementation of Problem Solving Model to Train Students Creative Thingking Skill.Unesa.Jurnal of Chemical Education. 1 (2): 40-45.

Safaat, Nazrudin. (2012). Pemrograman Aplikasi Mobile Smartphone dan Tablet PC Berbasis Android. Bandung: Informatika.

Santyasa, I Wayan. (2009). Metode Penelitian Pengembangan dan Teori Pengembangan Modul. Jogjakarta: Universitas Gadjah Mada.

Sappaile, N. (2019). Hubungan Pemahaman Konsep Perbandingan dengan Hasil Belajar Kimia Materi Stoikiometri. Jurnal Ilmu Pendidikan (JIP) STKIP Kusuma Negara Jakarta, 10(2), 58-71.

Supriadi, S., Wildan, W., Hakim, A., Savalas, L. T., \& Haris, M. (2021). Model Mental dan Kemampuan Spasial Mahasiswa Tahun Pertama dan Ketiga Pendidikan Kimia di Universitas Mataram. Jurnal Pijar Mipa, 16(3), 282-287.Suyanti, R.D. 2012.StrategiPembelajaran Kimia.Yogyakarta: Graha Ilmu.

Syaifuddin, A., Fadiawati, N., \& Rosilawati, I. (2014). Pengembangan Instrumen Asesmen Berbasis Representasi Kimia Pada Materi Larutan Elektrolit dan Nonelektrolit. Jurnal Pendidikan dan Pembelajaran Kimia, 3(2), 139354. W. Sanjaya. 2013. Penelitian Pendidikan: Jenis, Metode dan Prosedur. Jakarta: Kencana. 